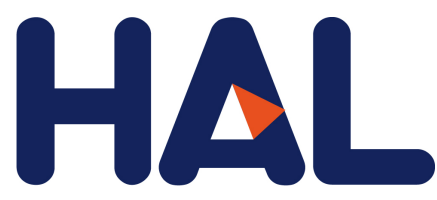

archives-ouvertes

\title{
Draft genome sequence of Promicromonospora panici sp. nov., a novel ionizing-radiation-resistant actinobacterium isolated from roots of the desert plant Panicum turgidum
}

Sihem Guesmi, Imen Nouioui, Petar Pujic, Audrey Dubost, Afef Najjari, Kais

Ghedira, José Igual, Ameur Cherif, Hans-Peter Klenk, Haïtham Sghaier, et al.

\section{To cite this version:}

Sihem Guesmi, Imen Nouioui, Petar Pujic, Audrey Dubost, Afef Najjari, et al.. Draft genome sequence of Promicromonospora panici sp. nov., a novel ionizing-radiation-resistant actinobacterium isolated from roots of the desert plant Panicum turgidum. Extremophiles, Springer Verlag, 2021, 25 (1), pp.25-38. 10.1007/s00792-020-01207-8 . hal-03378213

\section{HAL Id: hal-03378213 \\ https://hal.archives-ouvertes.fr/hal-03378213}

Submitted on 14 Oct 2021

HAL is a multi-disciplinary open access archive for the deposit and dissemination of scientific research documents, whether they are published or not. The documents may come from teaching and research institutions in France or abroad, or from public or private research centers.
L'archive ouverte pluridisciplinaire HAL, est destinée au dépôt et à la diffusion de documents scientifiques de niveau recherche, publiés ou non, émanant des établissements d'enseignement et de recherche français ou étrangers, des laboratoires publics ou privés. 


\section{Metadata of the article that will be visualized in OnlineFirst}

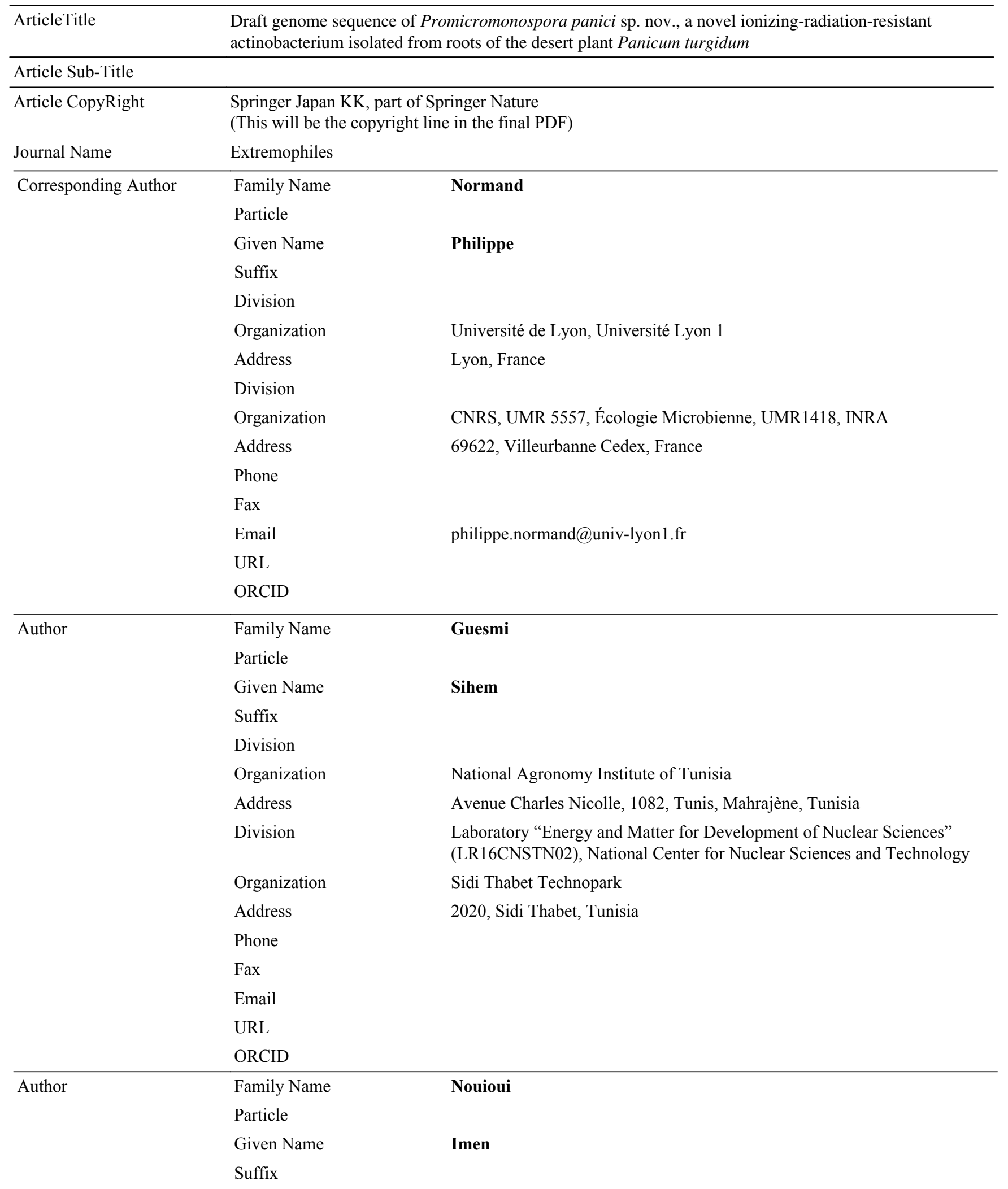


Division

Organization

Address

Division

Organization

Address

Phone

Fax

Email

URL

ORCID

\begin{tabular}{|c|c|c|}
\hline & \multicolumn{2}{|l|}{ Fax } \\
\hline & \multicolumn{2}{|l|}{ Email } \\
\hline & \multicolumn{2}{|l|}{ URL } \\
\hline & \multicolumn{2}{|l|}{ ORCID } \\
\hline \multirow[t]{15}{*}{ Author } & Family Name & Pujic \\
\hline & Particle & \\
\hline & Given Name & Petar \\
\hline & Suffix & \\
\hline & Division & \\
\hline & Organization & Université de Lyon, Université Lyon 1 \\
\hline & Address & Lyon, France \\
\hline & Division & \\
\hline & Organization & CNRS, UMR 5557, Écologie Microbienne, UMR1418, INRA \\
\hline & Address & 69622, Villeurbanne Cedex, France \\
\hline & Phone & \\
\hline & Fax & \\
\hline & Email & \\
\hline & URL & \\
\hline & ORCID & \\
\hline \multirow[t]{15}{*}{ Author } & Family Name & Dubost \\
\hline & Particle & \\
\hline & Given Name & Audrey \\
\hline & Suffix & \\
\hline & Division & \\
\hline & Organization & Université de Lyon, Université Lyon 1 \\
\hline & Address & Lyon, France \\
\hline & Division & \\
\hline & Organization & CNRS, UMR 5557, Écologie Microbienne, UMR1418, INRA \\
\hline & Address & 69622, Villeurbanne Cedex, France \\
\hline & Phone & \\
\hline & Fax & \\
\hline & Email & \\
\hline & URL & \\
\hline & ORCID & \\
\hline \multirow[t]{3}{*}{ Author } & Family Name & Najjari \\
\hline & Particle & \\
\hline & Given Name & Afef \\
\hline
\end{tabular}

School of Natural and Environmental Sciences

Newcastle University

Ridley Building 2, Newcastle upon Tyne, NE1 7RU, UK

Leibniz Institute DSMZ-German Collection of Microorganisms and Cell Cultures

Braunschweig, Germany 
Suffix

Division

Organization

Université de Tunis el Manar, Faculté des Sciences de Tunis, LR03ES03 Microorganismes et Biomolécules Actives

Address

2092, Tunis, Tunisia

Phone

Fax

Email

URL

ORCID

\begin{tabular}{|c|c|c|}
\hline \multirow[t]{12}{*}{ Author } & Family Name & Ghedira \\
\hline & Particle & \\
\hline & Given Name & Kais \\
\hline & Suffix & \\
\hline & Division & Laboratory of Bioinformatics, Biomathematics and Biostatistics-LR16IPT09 \\
\hline & Organization & Institut Pasteur de Tunis, Université de Tunis El Manar \\
\hline & Address & 1002, Tunis, Tunisia \\
\hline & Phone & \\
\hline & Fax & \\
\hline & Email & \\
\hline & URL & \\
\hline & ORCID & \\
\hline \multirow[t]{12}{*}{ Author } & Family Name & Igual \\
\hline & Particle & \\
\hline & Given Name & José M. \\
\hline & Suffix & \\
\hline & Division & \\
\hline & Organization & $\begin{array}{l}\text { Instituto de Recursos Naturales y Agrobiología de Salamanca, Consejo } \\
\text { Superior de Investigaciones Científicas (IRNASA-CSIC) }\end{array}$ \\
\hline & Address & c/Cordel de Merinas 40-52, 37008, Salamanca, Spain \\
\hline & Phone & \\
\hline & Fax & \\
\hline & Email & \\
\hline & URL & \\
\hline & ORCID & \\
\hline \multirow[t]{11}{*}{ Author } & Family Name & Cherif \\
\hline & Particle & \\
\hline & Given Name & Ameur \\
\hline & Suffix & \\
\hline & Division & \\
\hline & Organization & University Manouba, ISBST, BVBGR-LR11ES31, \\
\hline & Address & Biotechpole Sidi Thabet, 2020, Ariana, Tunisia \\
\hline & Phone & \\
\hline & Fax & \\
\hline & Email & \\
\hline & URL & \\
\hline
\end{tabular}


ORCID

\begin{tabular}{|c|c|c|}
\hline \multirow[t]{12}{*}{ Author } & Family Name & Klenk \\
\hline & Particle & \\
\hline & Given Name & Hans-peter \\
\hline & Suffix & \\
\hline & Division & School of Natural and Environmental Sciences \\
\hline & Organization & Newcastle University \\
\hline & Address & Ridley Building 2, Newcastle upon Tyne, NE1 7RU, UK \\
\hline & Phone & \\
\hline & Fax & \\
\hline & Email & \\
\hline & URL & \\
\hline & ORCID & \\
\hline \multirow[t]{16}{*}{ Author } & Family Name & Sghaier \\
\hline & Particle & \\
\hline & Given Name & Haïtham \\
\hline & Suffix & \\
\hline & Division & $\begin{array}{l}\text { Laboratory "Energy and Matter for Development of Nuclear Sciences" } \\
\text { (LR16CNSTN02), National Center for Nuclear Sciences and Technology }\end{array}$ \\
\hline & Organization & Sidi Thabet Technopark \\
\hline & Address & 2020, Sidi Thabet, Tunisia \\
\hline & Division & \\
\hline & Organization & University Manouba, ISBST, BVBGR-LR11ES31, \\
\hline & Address & Biotechpole Sidi Thabet, 2020, Ariana, Tunisia \\
\hline & Phone & \\
\hline & Fax & \\
\hline & Email & \\
\hline & URL & \\
\hline & ORCID & \\
\hline & Received & 24 May 2019 \\
\hline \multirow[t]{2}{*}{ Schedule } & Revised & \\
\hline & Accepted & 7 October 2020 \\
\hline Abstract & \multicolumn{2}{|c|}{ 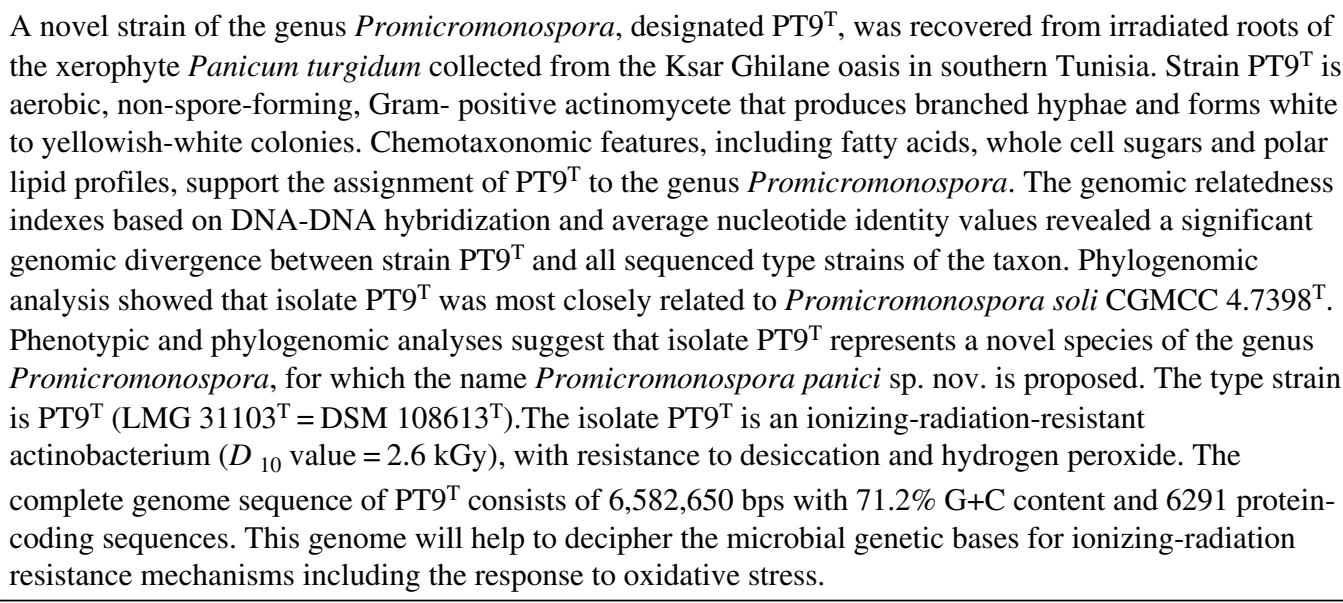 } \\
\hline
\end{tabular}


Keywords (separated by '-') Ionizing-radiation resistant - Genome sequence - Ksar Ghilane oasis - Polyphasic taxonomy Promicromonospora panici - Oxidative stress

Footnote Information Communicated by A. Oren.

Electronic supplementary material The online version of this article (https://doi.org/10.1007/ s00792-020-01207-8) contains supplementary material, which is available to authorized users. 


\title{
2 Draft genome sequence of Promicromonospora panici sp. nov., a novel 3 ionizing-radiation-resistant actinobacterium isolated from roots 4 of the desert plant Panicum turgidum
}

5 Sihem Guesmi $i^{1,2} \cdot$ Imen Nouioui $^{3,4} \cdot$ Petar Pujic $^{5,6} \cdot$ Audrey Dubost $^{5,6} \cdot$ Afef Najjari $^{7} \cdot$ Kais Ghedira $^{8} \cdot$ José M. $^{\text {Igual }}{ }^{9}$.
6 Ameur Cherif $^{10} \cdot$ Hans-peter Klenk $^{3} \cdot$ Haïtham Sghaier

7 Received: 24 May 2019/ Accepted: 7 October 2020

\begin{abstract}
A novel strain of the genus Promicromonospora, designated $\mathrm{PT} 9^{\mathrm{T}}$, was recovered from irradiated roots of the xerophyte Panicum turgidum collected from the Ksar Ghilane oasis in southern Tunisia. Strain PT9 ${ }^{\mathrm{T}}$ is aerobic, non-spore-forming, Gram- positive actinomycete that produces branched hyphae and forms white to yellowish-white colonies. Chemotaxonomic AQ1 features, including fatty acids, whole cell sugars and polar lipid profiles, support the assignment of $\mathrm{PT} 9^{\mathrm{T}}$ to the genus Promicromonospora. The genomic relatedness indexes based on DNA-DNA hybridization and average nucleotide identity values revealed a significant genomic divergence between strain $\mathrm{PT}^{\mathrm{T}}$ and all sequenced type strains of the taxon. Phylogenomic $\mathbf{A Q 3}$ analysis showed that isolate $\mathrm{PT} 9^{\mathrm{T}}$ was most closely related to Promicromonospora soli CGMCC $4.7398^{\mathrm{T}}$. Phenotypic and phylogenomic analyses suggest that isolate $\mathrm{PT}^{\mathrm{T}}$ represents a novel species of the genus Promicromonospora, for which the name Promicromonospora panici sp. nov. is proposed. The type strain is $\mathrm{PT}^{\mathrm{T}}\left(\mathrm{LMG} 31103^{\mathrm{T}}=\mathrm{DSM} 108613^{\mathrm{T}}\right)$. The isolate $\mathrm{PT} 9^{\mathrm{T}}$ is an ionizing-radiation-resistant actinobacterium $\left(D_{10}\right.$ value $\left.=2.6 \mathrm{kGy}\right)$, with resistance to desiccation and hydrogen peroxide. The complete genome sequence of $\mathrm{PT} 9^{\mathrm{T}}$ consists of $6,582,650 \mathrm{bps}$ with $71.2 \% \mathrm{G}+\mathrm{C}$ content and 6291 protein-coding sequences. This genome will help to decipher the microbial genetic bases for ionizing-radiation resistance mechanisms including the response to oxidative stress.
\end{abstract}

Keywords Ionizing-radiation resistant · Genome sequence $\cdot$ Ksar Ghilane oasis · Polyphasic taxonomy ·

Promicromonospora panici . Oxidative stress
Abbreviations
DSBs Double-strand breaks
ROS Reactive oxygen species
ANI Average nucleotide identity
isDDH In silico DNA-DNA hybridization
IR Ionizing radiation
kGy Kilogray
TSA Tryptic soy agar
TSB Tryptic soy broth

Communicated by A. Oren.

Electronic supplementary material The online version of this article (https://doi.org/10.1007/s00792-020-01207-8) contains supplementary material, which is available to authorized users.

Philippe Normand

philippe.normand@univ-lyon1.fr

Extended author information available on the last page of the article

\section{Introduction}

The genus Promicromonospora, belonging to the family Promicromonosporaceae, was first proposed by Krasil'nikov et al. (1961). This genus is phylogenetically closely related to the genera Cellulosimicrobium and Oerskovia (Schumann et al. 2001; Busse et al. 2003). Members of the genus are aerobic and Gram-positive actinomycetes. Their major characteristics are a branched substrate mycelium that fragments into rod-shaped or coccoid elements, iso- and anteisobranched as the predominant cellular fatty acids, MK- $9\left(\mathrm{H}_{4}\right)$ as the major menaquinone and a DNA $\mathrm{G}+\mathrm{C}$ content of 70-75\% (Schumann and Stackebrandt 2012).

Promicromonospora genus contains 18 species that have been isolated from various biotopes, such as air in the medieval Vienna (Busse et al. 2003), medicinal plant Maytenus austroyunnanensis in Yunnan Province (Qin et al. 2012), the surface-sterilized root of a pine tree in Australia (Kaewkla et al. 2017), soil in Mount Song (Zheng et al. 
2017), etc. However, it is important to note that the number of validly named species is 14 as of August 08, 2020, available at https://lpsn.dsmz.de/genus/promicromonospo ra, including Promicromonospora soli (Zheng et al. 2017), Promicromonospora kermanensis (Mohammadipanah et al. 2017), Promicromonospora callitridis (Kaewkla and Franco 2017), Promicromonospora alba (Guo et al. 2016) and Promicromonospora iranensis (Mohammadipanah et al. 2014), among the most recently described species.

Promicromonospora strains have industrially and environmentally valuable applications owing to the production of various bioactive molecules (Gabani and Singh 2013; Thomas et al. 2016), such as antibiotics (Izumikawa et al. 2011), xylanase (Kumar et al. (2011), cellulase (Thomas et al. 2016), xylanilyticolides (Jin et al. 2018), etc. Furthermore, Promicromonospora genus showed interesting biological properties, such as antimicrobial activity against bacteria and yeast pathogens (Zothanpuia et al. 2018), bioremediation by the removal of cadmium from polluted waste (Hamedi et al. 2015), plant growth-promoting rhizobacterium through the production of gibberellins (Kang et al. 2012, 2014), etc.

Despite the potential applications of Promicromonospora species, there have been a limited number of reports that investigated genomic and phenotypic aspects such as multiresistance to extreme conditions (radiation, desiccation, oxidative stress, etc.) of this genus members. The number of related genomes available at the National Center for Biotechnology Information (NCBI) and the Genomes OnLine Database is limited to 25 as of August 08, 2020.

In this study, we report the phenotypic, phylogenetic and genomic characterization of a novel actinomycete species, Promicromonospora panici sp. nov., with insights into its tolerance to ionizing radiation (IR), desiccation and oxidative stress.

\section{Materials and methods}

\section{Strain isolation and cultivation}

PT9 $^{\mathrm{T}}$ was isolated from irradiated roots of $P$. turgidum, which were collected in May 2015 from the oasis Ksar Ghilane (Tunisia, coordinates N 3259.557', E 9³6.941', $221.9 \mathrm{~m}$ above sea level) at the gates of the Sahara Desert. One-gram root sample aliquots were exposed to levels of IR at a dose of 10 kilogray ( $\mathrm{kGy}$ ) with a mean rate dose of $25.6 \mathrm{kGy} / \mathrm{h}$ at room temperature using a cobalt-60 gamma irradiator at the National Center for Nuclear Sciences and Technology (CNSTN), Tunisia. After gamma irradiation, the $1 \mathrm{~g}$ root samples were mixed with $9 \mathrm{~mL}$ of $0.9 \% \mathrm{NaCl}$ solution (w/v) and shaken on a rotary shaker at $250 \mathrm{rpm}$, $30{ }^{\circ} \mathrm{C}$ for $1 \mathrm{~h}(\mathrm{~h})$. Then, $100 \mu \mathrm{L}$ sample of the suspension was serially diluted $\left(10^{-5}-10^{-9}\right)$ and spread onto tryptic soy agar (TSA) medium (contains $15 \mathrm{~g} / \mathrm{L}$ of tryptone, $5 \mathrm{~g} / \mathrm{L}$ of soy peptone, $5 \mathrm{~g} / \mathrm{L}$ of sodium chloride and $15 \mathrm{~g} / \mathrm{L}$ of bacteriological agar, at $\mathrm{pH} 7$ ). After 7 days of aerobic incubation at $30{ }^{\circ} \mathrm{C}$, colonies were transferred and purified on liquid medium using tryptic soy broth (TSB) and maintained as $20 \%$ (v/v) glycerol suspensions at -20 and $-80^{\circ} \mathrm{C}$ (Rainey et al. 2005).

For routine work, $\mathrm{PT} 9^{\mathrm{T}}$ was cultured aerobically on solid TSA medium and liquid TSB medium for 3 days at $30^{\circ} \mathrm{C}$. Isolate $\mathrm{PT}^{\mathrm{T}}$ was deposited in the BCCM collection (Belgian Coordinated Collections of Microorganisms) and the DSMZ collection (Deutsche Sammlung von Mikroorganismen und Zellkulturen $\mathrm{GmbH}$ ) under the deposit numbers LMG 31,103 and DSM 108,613, respectively.

\section{Morphological and phenotypic characteristics}

Colony morphology of isolate $\mathrm{PT}^{\mathrm{T}}$ was observed by using cells grown on TSA at $30{ }^{\circ} \mathrm{C}$ for 2 days. Gram staining was assessed using the standard Gram stain method and spore motility was carried out by optical light and epifluorescence microscopy (Leica Microsystems, Germany) observation of cells suspended in phosphate buffer (at pH 7). For the observation of morphological characteristics, bacterial cells growing on TSA medium at $30^{\circ} \mathrm{C}$ for $72 \mathrm{~h}$, were harvested with $2 \%$ glutaraldehyde in saline solution $(0.9 \%$ of $\mathrm{NaCl})$ and then fixed cells were dried in a graded ethanol series (50, 70, 90 and 100\% of ethanol) (Kaewkla and Franco 2019). Observations were done via a scanning electron microscope (JSM 5400.JEOL, Japan).

Growth of isolate was checked on Luria-Bertani (LB) (sodium chloride $10 \mathrm{~g} / \mathrm{L}$, tryptone $10 \mathrm{~g} / \mathrm{L}$, yeast extract $5 \mathrm{~g} / \mathrm{L}$ ), nutrient agar (meat extract $10 \mathrm{~g} / \mathrm{L}$, peptone $10 \mathrm{~g} / \mathrm{L}$, sodium chloride $5 \mathrm{~g} / \mathrm{L}$, agar $15 \mathrm{~g} / \mathrm{L}$ at $\mathrm{pH}$ 7.3), R2YE medium (is a variation of $\mathrm{R} 2$ containing yeast extract) (sucrose $10.3 \mathrm{~g} / \mathrm{L}, \mathrm{K} 2 \mathrm{SO} 40.25 \mathrm{~g} / \mathrm{L}, \mathrm{MgCl} 2 \cdot 6 \mathrm{H} 2 \mathrm{O}$ $10.12 \mathrm{~g} / \mathrm{L}$, glucose $10 \mathrm{~g} / \mathrm{L}$, casamino acid $0.1 \mathrm{~g} / \mathrm{L}$, yeast extract $5 \mathrm{~g} / \mathrm{L}$, agar $15 \mathrm{~g} / \mathrm{L}$ ), soya flour mannitol agar (soya flour $2 \mathrm{~g} / \mathrm{l}$, mannitol $20 \mathrm{~g} / \mathrm{L}$, agar $20 \mathrm{~g} / \mathrm{L}$ ), starch casein agar (starch $10 \mathrm{~g} / \mathrm{L}$, casein powder $10 \mathrm{~g} / \mathrm{L}$, agar $15 \mathrm{~g} / \mathrm{L}$ at $\mathrm{pH}$ 7.2) and in TSA medium at $30{ }^{\circ} \mathrm{C}$ for $72 \mathrm{~h}$. The optimal temperature for growth was tested by checking growth on TSA over a range of $10-60{ }^{\circ} \mathrm{C}$ with $5^{\circ} \mathrm{C}$ intervals. The $\mathrm{pH}$ range for growth was examined over a range $\mathrm{pH} 4-10$ with 1 $\mathrm{pH}$ unit intervals in TSB over 3 days of incubation at $30{ }^{\circ} \mathrm{C}$. Tolerance of $\mathrm{NaCl}$ was evaluated in TSB supplemented with $0-15.0 \%(\mathrm{w} / \mathrm{v}) \mathrm{NaCl}$ (at $2.0 \%$ intervals) after incubation at $30{ }^{\circ} \mathrm{C}$ for $72 \mathrm{~h}$.

Catalase activity was determined by monitoring generation of bubbles upon the addition of a drop of 3\% hydrogen peroxide $\left(\mathrm{H}_{2} \mathrm{O}_{2}\right)$ solution (Smibert and Krieg 1994).
116 
Oxidase activity was assessed by the oxidation of $0.2 \%$ $(\mathrm{w} / \mathrm{v})$ oxidase reactive by monitoring the colour change.

For chemotaxonomic characterization, cells of $\mathrm{PT} 9^{\mathrm{T}}$ were maintained on yeast extract-malt extract agar (International Streptomyces Project medium 2; ISP2) medium which had been shaken at $180 \mathrm{rpm}$ and incubated for 7 days at $28{ }^{\circ} \mathrm{C}$. After incubation, the biomass of isolate PT9 ${ }^{\mathrm{T}}$ was harvested from ISP2 broth cultures. Then, cells were washed three times with sterile distilled water and freeze-dried. Whole-cell sugars were extracted according to the procedures of Lechevalier and Lechevalier (1970) and identified using thin layer chromatography (TLC) as described by Staneck and Roberts (1974). Whole-organism diaminopimelic acids were identified using the protocols of Schleifer and Kandler (1972). Polar lipids pattern was determined following the modified protocol of Minnikin et al. (1984) by Kroppenstedt and Goodfellow (2006). Cellular fatty acids were extracted according to the protocol of Miller (1982) with minor modification from Kuykendall et al. (1988). Fatty acid patterns were determined from the biomass of isolate PT9 ${ }^{\mathrm{T}}$ using the Standard Microbial Identification (MIDI) system Version 4.5 and the ACTIN6 database (Sasser 1990).

\section{Genome sequencing, molecular and phylogenetic analyses}

\section{Genomic DNA extraction}

Genomic DNA extraction from isolate $\mathrm{PT}^{\mathrm{T}}$ was performed as described previously by Marmur (1961) with a phenol/chloroform extraction step (Li et al. 2007). Cells from $50 \mathrm{~mL}$ cultures grown on TSB were collected by centrifugation (Eppendorf France) and the pellets were solubilized in $8 \mathrm{~mL}$ of $10 \mathrm{mM}$ Tris- $\mathrm{HCl}$ at $\mathrm{pH} 8,10 \mathrm{mg} /$ $\mathrm{mL}$ of lysozyme and $1 \mathrm{mM}$ of ethylenediaminetetraacetic acid (EDTA). Cells lysis was done on the ice during one hour, then $8 \mathrm{~mL}$ of $2 \% \mathrm{w} / \mathrm{vol}$ sodium dodecyl sulfate (SDS) and $2.8 \mathrm{mg} / \mathrm{mL}$ of proteinase $\mathrm{K}$ were added to the mix and incubated at $55{ }^{\circ} \mathrm{C}$ for $5 \mathrm{~h}$. Proteins and cell debris were removed by extraction with $16 \mathrm{~mL}$ of phenol, chloroform and isoamyl alcohol 25:24:1 (v/v/v) at $\mathrm{pH}$ 8.2. After centrifugation, the aqueous phase was transferred into a new tube and genomic DNA was precipitated by adding $1.5 \mathrm{~mL}$ of $3 \mathrm{M}$ sodium acetate and two volume of absolute ethanol. The DNA pellet was washed in $70 \%$ ethanol, air-dried and solubilized in TE buffer (Tris-EDTA buffer from Invitrogen ${ }^{\mathrm{TM}}, 10 \mathrm{mM}$ Tris and $0.1 \mathrm{mM}$ EDTA) at $\mathrm{pH}$ 8. The quality of extracted DNA was assessed by measuring the $\mathrm{A}_{260} / \mathrm{A}_{280}$ ratio using a Nanodrop (Implen NP80, Thermo Fisher Scientific, USA) spectrophotometer.

\section{Genome sequencing, assembly and annotation}

The genome sequencing of $\mathrm{PT} 9^{\mathrm{T}}$ was performed on the Illumina MiSeq ${ }^{\mathrm{TM}}$ platform (Illumina, USA) by Biofidal society, Vaulx-en-Velin, France (https://www.biofidal-lab.com) using NextGen High Throughput Sequencing. Thus, a standard Illumina shotgun library "Nextera XT DNA Library Prep" was constructed and sequenced using the Illumina MiSeq technology by synthesis. A paired-end sequencing strategy was used with an average size of $2 \times 300 \mathrm{bp}$ in length generated and a total number of reads of 25,425,220 bp obtained. Quality control of raw data was assessed using the FastQC tool (https://www.bioinformatics.babraham.ac.uk/projects/ fastqc). The Unicycler software was used for de novo assembly. Genome annotation was performed with the MicroScope platform version 3.10.0 using the integrated microbial genomes non-redundant database, KEGG and COG databases (Vallenet et al. 2017). Reads were processed and assembled as described by Castro-Wallace et al. (2017). The final draft assembly had an average depth coverage of 6.9 Mbp and 59 contigs. In addition, the percentage of $\mathrm{G}+\mathrm{C}$ in the complete genome sequence was calculated.

\section{Phylogenetic analysis and genomic comparisons}

Analysis of the 16S rDNA gene used the complete sequence retrieved from the genome using MAGE platform (Vallenet et al. 2009). This gene was identical to the $16 \mathrm{~S}$ rDNA gene sequence originally deposited in GenBank (MG712873) after the initial single colony isolation and amplification by polymerase chain reaction using the universal $27 \mathrm{~F}$ and 1492R primers (Sun et al. 2010). The resulting 16S rDNA gene sequence was compared with those of all validly named species using the EzTaxon database EzBioCloud (https:// www.ezbiocloud.net/identify/) (Yoon et al. 2017) and the web tool leBIBI(QBPP) available at https://umr5558-bibis erv.univ-lyon1.fr/lebibi/lebibi.cgi (Flandrois et al. 2015). The phylogenetic tree highlighting the position of $\mathrm{PT}^{\mathrm{T}}$ relative to the type strains of the other species within the genus Promicromonospora was constructed using W-IQ-TREE software accessed at https://iqtree.cibiv.univie.ac.at/, (Trifinopoulos et al. 2016) based on the Shimodaira-Hasegawa approximate likelihood ratio (SH-aLRT) (\%) (Guindon et al. 2010) and the ultrafast bootstrap (UFboot) (\%) (Minh et al. 2013).

These 16S rDNA sequence data have been submitted to the DDBJ/EMBL/GenBank databases through https://submi t.ncbi.nlm.nih.gov/ under accession number MG712873. Genome based phylogenetic tree was constructed using a high throughput wed server, Type Strain Genome server (TYG) available in the Genome to Genome Distance Calculator webserver (Meier-Kolthoff and Göker 2019). 
Average nucleotide identity (ANI) values between the genome of isolate $\mathrm{PT} 9^{\mathrm{T}}$ and those of the type strains of Promicromonospora species were calculated using best hits and reciprocal best hits between two genomic datasets as described by Yoon et al. (2017) available at (https://www. ezbiocloud.net/tools/ani). The top hits of the 16S rDNArelated strains of $\mathrm{PT}^{\mathrm{T}}{ }^{\mathrm{T}}$ were identified via the in silico calculation of digital DNA-DNA hybridization (dDDH) values between strains determination, using the Genometo-Genome Distance Calculator (GGDC) web server (https ://ggdc.dsmz.de/distcalc2.php) (Goris et al. 2007; MeierKolthoff et al. 2013).

\section{Growth under extreme conditions}

The resistance of isolate $\mathrm{PT} 9^{\mathrm{T}}$ to extreme conditions was assessed under IR, desiccation and hydrogen peroxide stress. The tolerance to gamma irradiation was assayed using cultures of $\mathrm{PT}^{\mathrm{T}}$ and Escherichia coli grown in TSB medium and LB agar, respectively at $30{ }^{\circ} \mathrm{C}$ for 3 days. Thus, $E$. coli DH5 $\alpha$ was used as an IR-sensitive bacterium (BebloVranesevic et al. 2018) for comparative analyses. Briefly, bacterial cells were collected, washed twice with a $0.9 \%$ $\mathrm{NaCl}$ solution, homogenized and subsequently resuspended in the same solution of $\mathrm{NaCl}$. Survival rates after exposure to a range of gamma radiation doses (1-5 kGy) were determined using the 3-(4, 5-dimethyl imidazole-2-yl)-2, 5-diphenyltetrazolium bromide (MTT) assay (Mosmann 1983). Bacterial cells were exposed to levels of gamma irradiation at a dose ranging from 1 to $5 \mathrm{kGy}$ using a cobalt- 60 gamma irradiator at the National Center for Nuclear Sciences and Technology (CNSTN), Tunisia. A volume of $10 \mu \mathrm{L}$ of MTT solution $(5 \mathrm{mg} / \mathrm{mL})$ was added to $100 \mu \mathrm{L}$ of irradiated cells and kept in the dark for $3 \mathrm{~h}$ at $37^{\circ} \mathrm{C}$. Results are represented with the corresponding controls not exposed to gamma irradiation, normalized to $100 \%$ (Morini et al. 2017). After incubation, the absorbance in each well was measured, including blanks, at $570 \mathrm{~nm}$ using a microtiter plate reader (Shimadzu, UV-1800). The value of $D_{10}(\mathrm{kGy})$, which is the dose necessary for a 90\% reduction in Colony Forming Units, was also calculated via RadioP1 (www.radiop.org.tn) (Benhamda et al. 2015) based on our experimental survival data.

The desiccation tolerance assay was performed in TSB medium according to Mattimore and Battista (1996). Briefly, $200 \mu \mathrm{L}$ of cell suspensions were pipetted into sterile Petri dishes and dried 28 days in a desiccator at $30{ }^{\circ} \mathrm{C}$. E. coli $\mathrm{DH} 5 \alpha$ was used as a desiccation-sensitive bacterium (Beblo-Vranesevic et al. 2018) for comparative analyses. After 28 days, samples were revived by washing the cells off the plate with $200 \mu \mathrm{L}$ of saline solution $(0.9 \% \mathrm{NaCl})$ to rehydrate the cells. Cell viability was examined using MTT assay, then $100 \mu \mathrm{L}$ of cell suspensions was transferred to a 96-well microplate and a volume of $10 \mu \mathrm{L}$ of MTT solution $(5 \mathrm{mg} / \mathrm{mL})$ was added. The microplate was incubated at room temperature in the dark for $3 \mathrm{~h}$ at $37^{\circ} \mathrm{C}$. After incubation, the absorbance of each well, including blank (without cells) which was normalized to $100 \%$, was measured at $570 \mathrm{~nm}$ using a microtiter plate reader (Shimadzu, UV-1800). The measured absorbance at OD $570 \mathrm{~nm}$ is proportional to the number of viable cells. The survival rate represents the absorbance at $570 \mathrm{~nm}$ after drying with a reference before drying. The package lethal (https://githu b.com/hofnerb/lethal) was used also to estimate the survival of $\mathrm{PT} 9^{\mathrm{T}}$ following exposure to desiccation.

Growth of isolate $\mathrm{PT}^{\mathrm{T}}$ with various concentrations of $\mathrm{H}_{2} \mathrm{O}_{2}$ (v/v) was also performed as described by Gholami et al. (2015). E. coli DH5 $\alpha$ was used as a proteome-oxidation-sensitive bacterium (Krisko et al. 2010) for comparative analyses. Fifty $\mu \mathrm{L}$ of bacterial suspensions were added to $100 \mu \mathrm{L}$ of TSB supplemented with $0-5 \%$ (v/v) of $\mathrm{H}_{2} \mathrm{O}_{2}$ using 96-well microplates. Plates were kept in the dark at $30{ }^{\circ} \mathrm{C}$ for $48 \mathrm{~h}$ with agitation at $120 \mathrm{rpm}$. The optical density was determined at $630 \mathrm{~nm}$ using a microplate reader TECAN (Infinite ${ }^{\circledR} 200$ PRO, Germany).

\section{Prediction of secondary metabolite clusters and genes related to oxidative stress response}

Clusters for secondary metabolites of isolate $\mathrm{PT} 9^{\mathrm{T}}$ were predicted using the antiSMASH (https://antismash.secondarym etabolites.org/\#!/start) version 4.0.2 software (Weber et al. 2015). Besides, in silico analyses of the genome $P T 9^{T}$ were done and genes implicated in scavenging of reactive oxygen species (ROS) were determined.

\section{Nucleotide sequence accession number}

The whole-genome shotgun sequence of isolate PT9 ${ }^{\mathrm{T}}$ was submitted to GenBank/ENA under BioProject accession number PRJEB29453 (ERP111755), BioSample number SAMEA5056529 and SRA accession number ERS2867704. Contig sequences of the de novo assembly were deposited at EMBL under the accession numbers UWYY01000000-UWYY01000056.

\section{Results and discussion}

\section{Cultural and phenotypic characteristics}

PT9 ${ }^{\mathrm{T}}$ was isolated from the irradiated roots of Panicum turgidum, which were collected from the oasis of Ksar Ghilane in the south of Tunisia. The isolate is an aerobic, Grampositive, non-motile and non-spore-forming actinomycete. Colonies are white-pigmented on TSA medium (Fig. S1), like $P$. xylanilytica, which was isolated from the medicinal

3

5

6

7

8

9

0

1

3


plant Maytenus austroyunnanensis (Qin et al. 2012). Cells of PT9 ${ }^{\mathrm{T}}$ developed a branched substrate mycelium with a wrinkled and shining surface, the septate hyphae of which broke, at a later stage, into fragments of various sizes and rod-shaped elements (Fig. 1). This feature is shared by all members of the genus Promicromonospora (Krasil'nikov et al. 1961; Schumann and Stackebrandt 2012).

This actinobacterial isolate had an optimal growth on nutrient agar, R2YE (medium specific for Streptomyces genus), soya flour mannitol agar and TSA media after incubation at $30{ }^{\circ} \mathrm{C}$ for $72 \mathrm{~h}$. It grew moderately well on LB agar and starch casein agar media. Growth of isolate PT9 ${ }^{\mathrm{T}}$ was observed at $28-37{ }^{\circ} \mathrm{C}$ (optimum at $30^{\circ} \mathrm{C}$ ) and $\mathrm{pH}$ 6.0-9.0, like P. xylanilytica YIM $61515^{\mathrm{T}}$ (Qin et al. 2012). No growth was observed in the presence of $2 \% \mathrm{NaCl}$. Catalase and oxidase activities of $\mathrm{PT} 9^{\mathrm{T}}$ were positive, similar to $P$. xylanilytica YIM $61515^{\mathrm{T}}$ (Qin et al. 2012). Promicromonospora sukumoe was shown to have a very high endo-cellulase activity (Ventorino et al. 2015).

\section{Chemotaxonomic characteristics}

Chemotaxonomic features of isolate $\mathrm{PT} 9^{\mathrm{T}}$ matched those described for members of the genus Promicromonospora. Whole-organism hydrolysates of isolate $\mathrm{PT} 9^{\mathrm{T}}$ contained DL2,6-Diaminopimelic acid (DL-DAP) and galactose, glucose and ribose as whole cell sugars. These traits are the same as the close phylogenetic neighbor, P. soli CGMCC $4.7398^{\mathrm{T}}$ (Zheng et al. 2017).

Polar lipid profiles of $\mathrm{PT} 9^{\mathrm{T}}$ consisted of diphosphatidylglycerol (DPG), phosphatidylglycerol (PG), phosphatidylinositol (PI) and unidentified lipid (L), phospholipid (PL), phosphoglycolipid (PGL) and glycolipids $\left(\mathrm{GL}_{1-3}\right)$. These features are coherent with those $P$. soli CGMCC $4.7398^{\mathrm{T}}$ (Zheng et al. 2017) (Fig. S2). The major fatty acids (> 25\%)

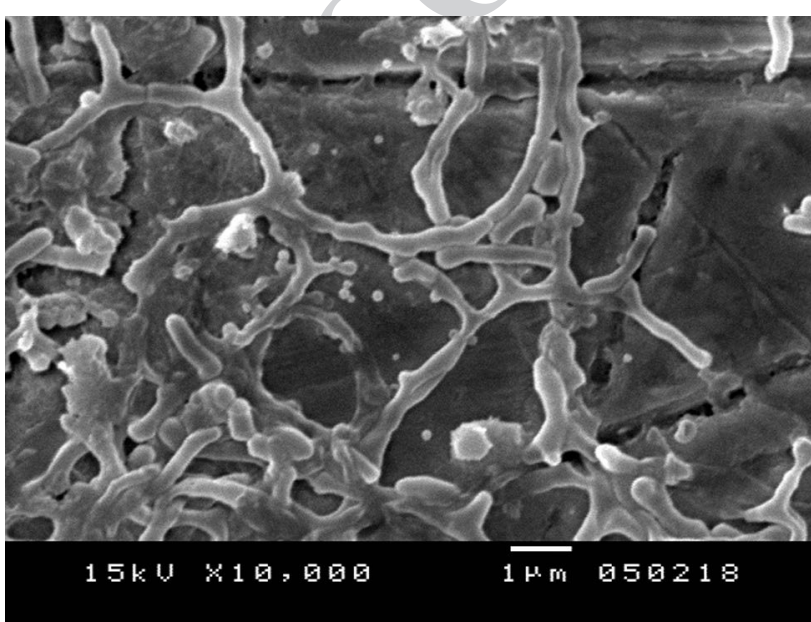

Fig. 1 XXX of $\mathrm{PT} 9^{\mathrm{T}}$ are anteiso- $\mathrm{C}_{15.0}(56.4 \%)$ and iso- $\mathrm{C}_{15.0}(26.9 \%)$ (Table S1), which are similar to those of $P$. soli CGMCC $4.7398^{\mathrm{T}}$ (Zheng et al. 2017).

The chemotaxonomic features of isolate $\mathrm{PT} 9^{\mathrm{T}}$ are in line with the genus Promicromonospora but are not enough to distinguish isolate $\mathrm{PT}^{\mathrm{T}}$ from its close neighbor. For this reason, phylogenetic analyses based on genomic comparisons were necessary to determine the taxonomic affiliation of isolate $\mathrm{PT} 9^{\mathrm{T}}$.

\section{Phylogeny and genomic comparisons}

Blast of the complete 16S rDNA gene sequence (1508 bp) of isolate $\mathrm{PT} 9^{\mathrm{T}}$ showed similarity values of $99.3 \%$ and $99.0 \%$ with P. xylanilytica YIM $61515^{\mathrm{T}}$, Promicromonospora aerolata DSM $15943^{\mathrm{T}}$ and P. iranensis DSM $45554^{\mathrm{T}}$, respectively. However, it decreased to $98.9 \%, 98.8 \%$, and $98.7 \%$ with Promicromonospora vindobonensis DSM $24547^{\mathrm{T}}$, Promicromonospora thailandica DSM $26652^{\mathrm{T}}$ and $P$. alba DSM $100490^{\mathrm{T}}$ and P. callitridis DSM $103339^{\mathrm{T}}$ (Table 1 ), respectively.

Comparison of the sequences of isolate $\mathrm{PT} 9^{\mathrm{T}}$ and type strains belonging to genus Promicromonospora revealed identity differences that are marginally within the cut-off value of $>1.3 \%$ (Stackebrandt and Ebers 2006).

The results of the 16S rDNA gene sequence similarity are not in line with the phylogenetic position of strain $\mathrm{PT} 9^{\mathrm{T}}$ in the 16S rDNA gene based tree (Fig. S3). Strain PT9 ${ }^{\mathrm{T}}$ occupied a poorly supported distinct branch loosely associated to a subclade housing several Promicromonospora spp. including the ones cited above and next to the type strain of $P$. soli. Thus, further information is required to determine the reliable phylogenetic position of isolate $\mathrm{PT} 9^{\mathrm{T}}$.

In the genome based phylogenetic tree (Fig. 2), strain $\mathrm{PT9}^{\mathrm{T}}$ was found to form a well-supported subclade closely related to the type strain of $P$. soli which was associated to the branch of Promicromonospora umidemergens DSM $22081^{\mathrm{T}}$.

16S rDNA gene sequence similarities between $\mathrm{PT}^{\mathrm{T}}$ and closely related type strains indicated the need to confirm the genomic distinctness of the type strain as representing a novel species by genomic relatedness indices. These analyses are necessary to further differentiate $\mathrm{PT} 9^{\mathrm{T}}$ from other species affiliated to the Promicromonospora genus.

Therefore, pairwise comparisons between isolate PT $9^{\mathrm{T}}$ and the available reference genomes were determined based on the proposed thresholds for recognition of genomic species, ANI and isDDH values. ANI values between $P$. panici $\mathrm{PT}^{\mathrm{T}}$ and closely related species ranged from 84.6 with $P$. sukumoe DSM $44121^{\mathrm{T}}$ to $86.95 \%$ with $P$. soli CGMCC $4.7398^{\mathrm{T}}$, which were below the cut-off level (95-96\%) for species delineation (Goris et al. 2007; Richter and Rossello-Mora 2009). Indeed, strain PT9 ${ }^{\mathrm{T}}$ 
Table 1 Identities of the strain PT9 ${ }^{\mathrm{T}}$ 16S rDNA gene to those of Promicromonospora type strains using EZbiocloud

\begin{tabular}{|c|c|c|c|c|}
\hline Rank & Name & Strain & Accession & $\begin{array}{l}\text { 16S rDNA } \\
\text { pairwise similar- } \\
\text { ity }(\%)\end{array}$ \\
\hline 1 & Promicromonospora xylanilytica & YIM $61515^{\mathrm{T}}$ & FJ214352 & 99.3 \\
\hline 2 & Promicromonospora aerolata & DSM $15943^{\mathrm{T}}$ & AJ487303 & 99.3 \\
\hline 3 & Promicromonospora iranensis & DSM $45554^{\mathrm{T}}$ & JN038073 & 99.0 \\
\hline 4 & Promicromonospora vindobonensis & DSM $24547^{\mathrm{T}}$ & AJ487302 & 98.9 \\
\hline 5 & Promicromonospora thailandica & DSM $26652^{\mathrm{T}}$ & AB560974 & 98.8 \\
\hline 6 & Promicromonospora alba & ${\underline{D S M} 100490^{\mathrm{T}}}$ & KP784765 & 98.7 \\
\hline 7 & Promicromonospora callitridis & ${\underline{\mathrm{DSM}} 103339^{\mathrm{T}}}$ & GU434237 & 98.7 \\
\hline 8 & Promicromonospora kroppenstedtii & DSM $19349^{\mathrm{T}}$ & KI911710 & 98.7 \\
\hline 9 & Promicromonospora endophytica & JCM $19560^{\mathrm{T}}$ & GU434253 & 98.7 \\
\hline 10 & Promicromonospora soli & CGMCC $4.7398^{\mathrm{T}}$ & KY352348 & 98.6 \\
\hline 11 & Promicromonospora sukumoe & ${\underline{D S M ~} 44121^{\mathrm{T}}}$ & AB023375 & 98.6 \\
\hline 12 & Promicromonospora citrea & DSM $43110^{\mathrm{T}}$ & X83808 & 98.5 \\
\hline 13 & Promicromonospora kermanensis & DSM $45485^{\mathrm{T}}$ & KJ780745 & 98.5 \\
\hline 14 & Promicromonospora umidemergens & $\underline{\mathrm{DSM}} 22081^{\mathrm{T}}$ & FN293378 & 98.3 \\
\hline
\end{tabular}

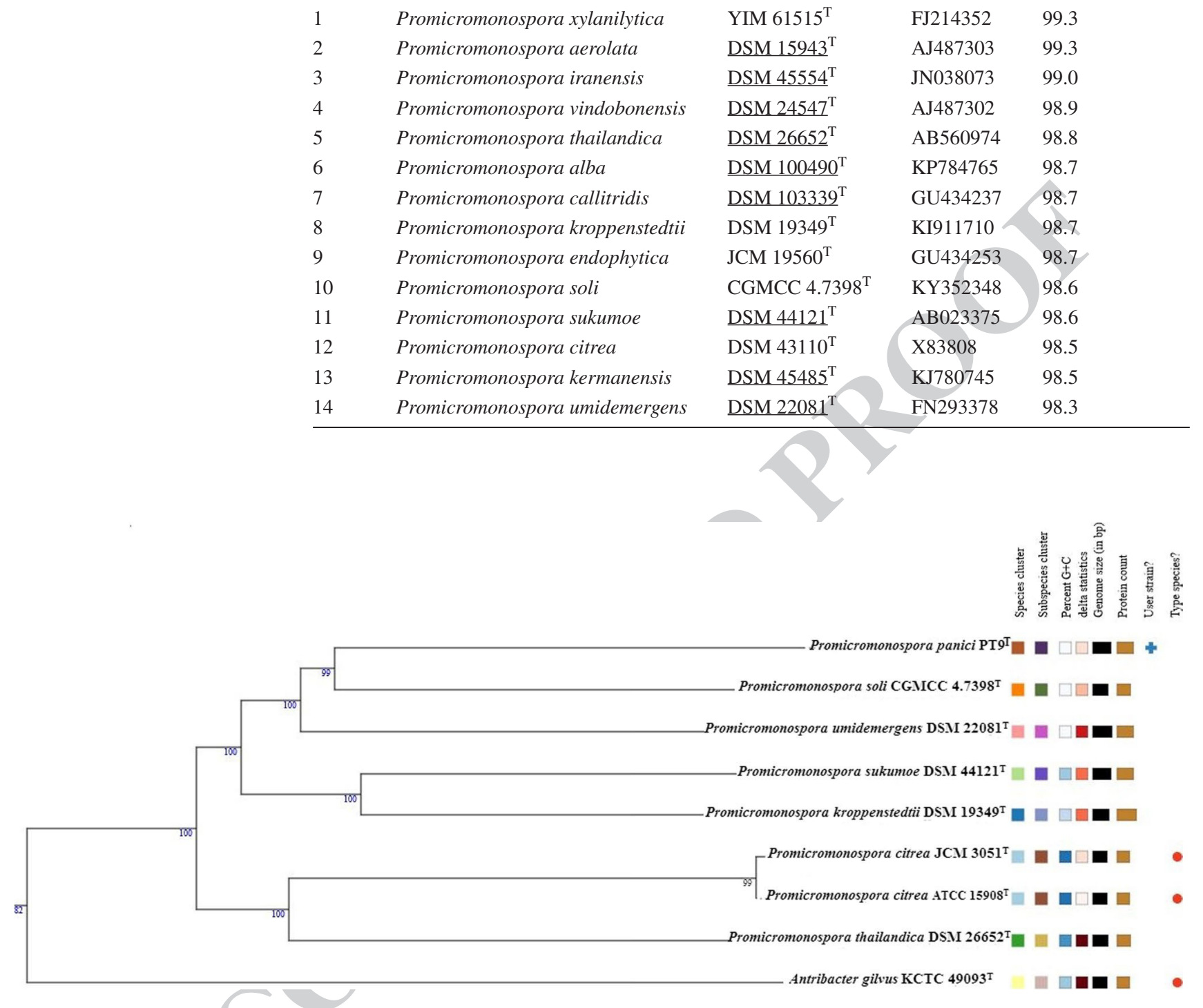

Fig. 2 XXX

displayed isDDH value of $32.8 \%$ with its closest neighbor P. soli CGMCC $4.7398^{\mathrm{T}}$ and $31.3 \%$ with Promicromonospora kroppenstedtii DSM $19349^{\mathrm{T}}$. DNA-DNA relatedness of $28.8 \%$ for isolate $\mathrm{PT}^{\mathrm{T}}$ against $P$. sukumoe DSM $44121^{\mathrm{T}}$. These values are well below the $70 \%$ cut-off value recommended for the circumscription of bacterial genomic species (Wayne et al. 1987; Chun et al. 2018).Thus, isDDH and ANI values indicated that $\mathrm{PT} 9^{\mathrm{T}}$ represents a novel species within the genus Promicromonospora.

Based on the morphological, phenotypic and genetic characteristics, it is evident that isolate $\mathrm{PT}^{\mathrm{T}}$ should be assigned to a novel species in the genus
Promicromonospora, for which the name Promicromonospora panici sp. nov. is proposed.

\section{Growth under extreme conditions}

The survival rate of $\mathrm{PT} 9^{\mathrm{T}}$ after exposure to IR was assessed. PT9 $^{\mathrm{T}}$ showed a marked survival profile following treatment with increasing doses of gamma radiation $(1-5 \mathrm{kGy})$, when compared to E. coli DH5 $\alpha$ (Fig. 3).

As shown in Fig. 3, there is a significant difference between survival profiles of $\mathrm{PT}^{\mathrm{T}}$ and the IR-sensitive strain $\mathrm{DH} 5 \alpha$. Indeed, the $\mathrm{D}_{10}$ value of $\mathrm{PT}^{\mathrm{T}}$ was around $2.6 \mathrm{kGy}$ 


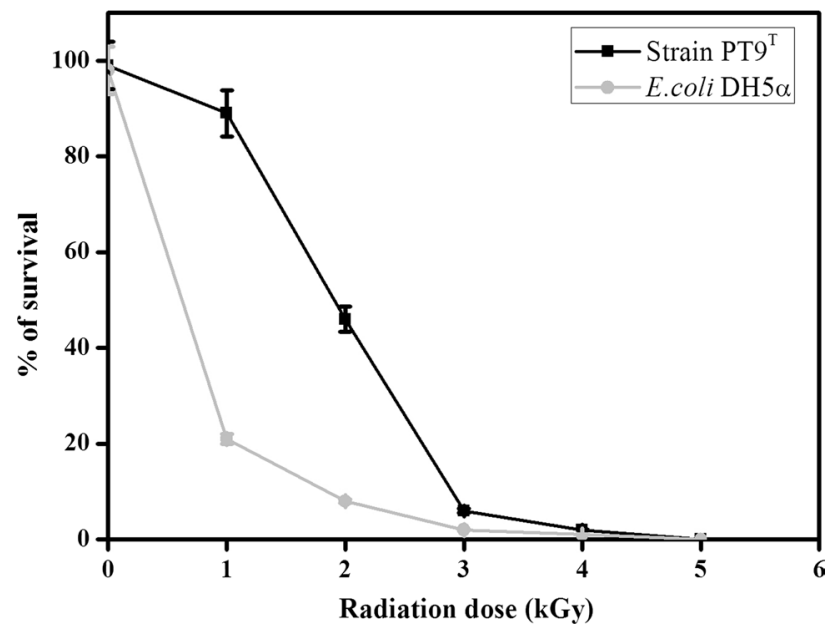

Fig. $3 \mathrm{XXX}$

(Fig. S4). To be considered an IR-resistant prokaryote, a bacterium should have a $\mathrm{D}_{10}$ value greater than $1 \mathrm{kGy}$ (Sghaier et al. 2008). Accordingly, $\mathrm{PT}^{\mathrm{T}}\left(D_{10}=2.6 \mathrm{kGy}\right)$ was described as an IR-resistant actinobacterium. Furthermore, the desiccation of isolate $\mathrm{PT}^{\mathrm{T}}$ for 28 days resulted in an overall loss of culturable cells $(\mathrm{CFU} / \mathrm{mL})$ of approximately $32 \%$ (Fig. S5). Also, the survival rate for this Saharan actinobacterium after 28 days of desiccation was $68 \%$ (Fig. S6). Thus, it is legitimate to conclude that $\mathrm{PT}^{\mathrm{T}}$ is also tolerant to desiccation.

The evaluation of resistance to $\mathrm{H}_{2} \mathrm{O}_{2}$ of PT10 was also assessed at various concentrations from 1 to $5 \%(\mathrm{v} / \mathrm{v})$ (Fig. 4).

As shown in Fig. 4, $\mathrm{PT} 9^{\mathrm{T}}$ is tolerant to $\mathrm{H}_{2} \mathrm{O}_{2}$ at concentrations ranging from 1 to $3 \%(\mathrm{v} / \mathrm{v})$, when compared to $E$. coli $\mathrm{DH} 5 \alpha$. However, the growth of PT9 ${ }^{\mathrm{T}}$ was almost completely inhibited at a concentration of $5 \%(\mathrm{v} / \mathrm{v})$ of $\mathrm{H}_{2} \mathrm{O}_{2}$.

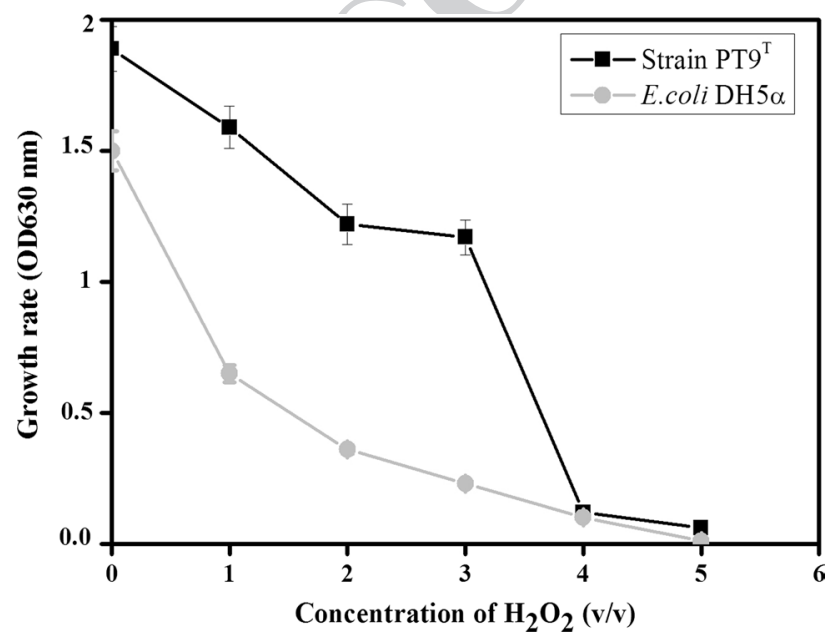

Fig. 4 XXX
Table 2 Genome features of P. panici $\mathrm{PT}^{\mathrm{T}}$

\begin{tabular}{ll}
\hline Features & Chromosome \\
\hline Genome size (bps) & $6,582,650$ \\
Contig numbers & 39 \\
G+C content (\%) & 71.2 \\
Number of Scaffolds & 59 \\
Number of Contigs & 59 \\
Average CDS length (bp) & 984.18 \\
Protein coding density (\%) & 91.9 \\
Number of genomic objects & 6368 \\
Protein coding genes CDSs & 6291 \\
rRNA genes & 3 \\
tRNA genes & 51 \\
\hline
\end{tabular}

This is the first report that examined the growth under extreme conditions of a strain belonging to genus Promicromonospora. Isolate $\mathrm{PT} 9^{\mathrm{T}}$ is resistant to gamma radiation, desiccation and oxidative stress $\left(\mathrm{H}_{2} \mathrm{O}_{2}\right)$. The convergence and the similarity among desiccation and gamma radiation stress response pathways in Deinococcus radiodurans were explained by the common production of ROS, which induces oxidative damage to cells (Slade et al. 2011; Lim et al. 2019). Thus, IR-resistant prokaryotes can also be desiccation tolerant (Slade et al. 2011). However, it is necessary to note that some desiccation-sensitive prokaryotes can possess resistance to IR (Beblo-Vranesevic et al. 2018).

In this context, the 'radiation adaptation hypothesis' stipulates that desiccation tolerance could be a consequence to IR, as gene products contributing to IR may have been recruited in some microbes to serve an additional function that is desiccation tolerance (Sghaier et al. 2007). The multiresistance of isolate $\mathrm{PT}{ }^{\mathrm{T}}$ may be originating from its oxidative response mechanisms. Thus, the genome sequencing of $\mathrm{PT}^{\mathrm{T}}$ was performed to identify these mechanisms and the strategies used to thrive under extreme conditions, such as gamma radiation, desiccation, salt concentration, $\mathrm{H}_{2} \mathrm{O}_{2}$, etc.

\section{Genome sequence analysis and oxidative stress response}

\section{Genomic features}

The complete genome of $P$. panici $\mathrm{PT}^{\mathrm{T}}$ consists of $6,582,650$ bps in size and has an average $\mathrm{G}+\mathrm{C}$ content of $71.2 \%$. The size of the $\mathrm{PT}^{\mathrm{T}}$ chromosome is not similar to this of the most closely related strain $P$. soli CGMCC $4.7398^{\mathrm{T}}(5,378,526 \mathrm{bps})$. De novo assembly of the genome sequencing data of $\mathrm{PT} 9^{\mathrm{T}}$ resulted in 59 contigs and an average CDS length of $984.18 \mathrm{bp}$. The genome was predicted to contain 6368 protein-coding genes, with a $91.9 \%$ protein-coding density, 51 tRNA and 3 rRNA genes. General 
features for the complete genome of $\mathrm{PT} 9^{\mathrm{T}}$ are shown in Table 2.

For 6291 protein-coding genes, $75.08 \%$ (4723 CDSs) are classified in at least one Clusters of Orthologous Genes (COG) group. The most abundant categories are general function prediction (910); carbohydrate transport and metabolism (808); transcription (744); amino acid transport and metabolism (610); and inorganic ion transport and metabolism (405). The identification also of several categories involved in the defense of microorganisms, which are cell wall/membrane/envelope biogenesis (270); replication, recombination and repair (200); secondary metabolites biosynthesis, transport and catabolism (175); chaperones (151); defense mechanisms (116); and more others (Supporting information presented in Table S2).

\section{Prediction of genes related to oxidative stress response}

The genome sequence of PT9 ${ }^{\mathrm{T}}$ contains several genes implicated in response to oxidative stress (Table 3 ).

Several proteins detected in isolate $\mathrm{PT}^{\mathrm{T}}$ were reported to have a role in IR and desiccation resistance-associated mechanisms such as GyrAB, NucS, PolA, RadA, RecA, RecD, RecO, SodA, SoxR, SSB and UvrD (Lim et al. 2019). $\mathrm{PT}^{\mathrm{T}}$ contains also various proteins implicated in defense mechanisms related to oxidative stress response, such as universal stress protein UspA, class III stress response-related ATPase ClpC, Fe-S center for redox-sensing, putative ATPdependent helicase DinG, putative ABC transporter $\mathrm{YclH}$, ferric enterobactin transport ATP-binding protein FepC, daunorubicin/doxorubicin resistance ATP-binding protein DrrA. The proteins observed in response to oxidative stress of $D$. radiodurans were DNA repair proteins (PolA, RadA, RecA, RecF, RecO), DNA protein binding (ArgF, DnaE, HisS, RecN), ribosomal proteins (RplB, Rpsl, RpsR) and oxidation-reduction process proteins (GltA, NuoC) (Slade et al. 2009; Ujaoney et al. 2017; Gao et al. 2020).

Isolate $\mathrm{PT}^{\mathrm{T}}{ }^{\text {seems }}$ to possess genes involved in the protection of its cytosolic proteins from oxidation (such as $m n t A, m n t B, s o d A)$ and the repair of DNA double-strand breaks (DSBs) after exposure to IR ( $\operatorname{din} G$, hup, recA, rec $Q$, $s s b A$ ) (Lim et al. 2019). Several DNA repair genes, which were reported to contribute to radiation and oxidative stress resistance in $D$. radiodurans, such as $g y r A B, \operatorname{lig} D, \operatorname{lig} A, \operatorname{rec} C$ (Bellenberg et al. 2019; Lim et al. 2019), were also detected in the genome of isolate $\mathrm{PT}^{\mathrm{T}}$. Some genes of $D$. radiodurans, such as $\mathrm{recF}$ and $\mathrm{rec} O$, are extremely sensitive to gamma rays, which are required for recombination repair by an incomplete genome reconstitution, a reduced level of DNA breakdown and an absence of DNA synthesis (Bentchikou et al. 2010). RecF and $\operatorname{Rec} O$ genes play an essential role in DNA double-strand-break repair pathways through an extended synthesis-dependent strand annealing process
(ESDSA) (Bentchikou et al. 2010), which might be involved in the repair of DSBs and the DNA synthesis step of ESDSA for isolate $\mathrm{PT} 9^{\mathrm{T}}$.

Furthermore, the treatment of $D$. radiodurans R1 with IR (and also desiccation) induced the over-expression of several genes in responses to oxidative stress damages, such as recA and $u v r D$, which encode proteins that have been previously associated with DNA repair (Tanaka et al. 2004).

$\mathrm{PT}^{\mathrm{T}}$ contains also many DNA ligase paralogs (such as $\operatorname{lig} A, \operatorname{lig} C, \operatorname{lig} D)$ and putative DNA ligases. For instance, lig $D$ gene is involved in the bacterial non-homologous DNA end joining (NHEJ) pathway according to the study of Ishino and Narumi (2015). D. radiodurans possesses efficient oxidative damage protection mechanisms, such as NHEJ and CNDEJ (condensed nucleoid-dependent end joining) repair pathways, involving radiation-inducible proteins (Ishino and Narumi 2015). These DNA repair proteins, such as ATPdependent DNA ligase that was detected in the genome of $\mathrm{PT}^{\mathrm{T}}$, play a principal role in the CNDEJ pathway, which represents a DSBs repair system specific to radioresistant bacteria with a high degree of genome condensation.

PT9 ${ }^{\mathrm{T}}$ contains also desiccation tolerance-associated proteins, such as ferritin BfrB, pleiotropic regulatory protein DegT, HTH-type transcriptional regulator RcdA, manganese-containing peroxidase XpdC (Mn_catalase) (Lim et al. 2019).

Various enzymes involved in oxidative stress responses, such as catalase, superoxide dismutase, NADH-dependent oxidases, manganese-containing antioxidants, which provide an important role to protect radioresistant microorganisms (Cárdenas et al. 2012; Bellenberg et al. 2019). Catalase KatA, superoxide dismutase [Mn] SodA and manganese MntA were detected in the genome of $\mathrm{PT}^{\mathrm{T}}$.

Radioresistant microorganisms have various mechanisms of defense against ionizing radiation, desiccation, oxidative stress-generating agents and environmental stresses that can damage cell components, including the production of scavenging ROS, detoxification and repair systems (Lim et al. 2019). Deinococcus radiodurans, has developed efficient enzymatic and non-enzymatic antioxidant systems, involving different physiological determinants and well-regulated molecular mechanisms for tolerance to radiation, desiccation and oxidative stress (Timmins and Moe 2016; Bellenberg et al. 2019). D. radiodurans employs various strategies to prevent oxidative stress, including an efficient DNA repair system, ROSscavenging enzymes (catalase and superoxide dismutase), non-enzymatic antioxidants and transcriptional regulators (OxyR) (Munteanu et al. 2015; Chen et al. 2019). The genome sequence of $D$. radiodurans revealed the presence of homologues of most well-known prokaryotic DNA repair proteins involved in base excision repair, nucleotide excision repair, mismatch repair and recombination repair. 
Table 3 List of genes involved in response to oxidative stress

\begin{tabular}{|c|c|c|c|}
\hline Label & Length (pb) & Gene & Functional \\
\hline PROM_v1_370013 & 1239 & recF & DNA replication and repair protein $\mathrm{RecF}$ \\
\hline PROM_v1_20039 & 1449 & katA & Scavenge (Catabolism) vegetative catalase 1 \\
\hline PROM_v1_40259 & 2232 & $k a t G$ & Catalase/hydroperoxidase HPI(I) \\
\hline$\underline{\text { PROM v1 } 70135}$ & 606 & recR & RecA filament-DNA complex stabilisation factor \\
\hline$\underline{\text { PROM_v1 } 470015}$ & 510 & $d p s$ & DNA protection during starvation protein \\
\hline PROM_v1_210103 & 1848 & $\operatorname{rec} Q$ & ATP-dependent DNA helicase RecQ \\
\hline$\underline{\text { PROM v1 } 10004}$ & 549 & $s s b A$ & Single-strand DNA-binding protein SSB \\
\hline$\underline{\text { PROM_v1 } 10142}$ & 2628 & $\operatorname{clp} B$ & Protein disaggregation chaperone \\
\hline PROM_v1_50101 & 963 & $d r r A$ & Daunorubicin/doxorubicin resistance ATP-binding protein DrrA \\
\hline PROM_v1_330032 & 1779 & - & UMUC domain protein DNA-repair protein \\
\hline PROM_v1_270047 & 3621 & $m f d$ & Transcription-repair-coupling factor \\
\hline PROM_v1_230011 & 1755 & recN & DNA repair protein $\mathrm{RecN}$ \\
\hline PROM_v1_20182 & 1224 & recA & Multifunctional SOS repair factor \\
\hline PROM_v1_40053 & 747 & $\mathrm{recO}$ & DNA repair protein $\mathrm{RecO}$ \\
\hline PROM_v1_40152 & 2496 & $\operatorname{lig} D$ & Multifunctional non-homologous end joining DNA repair protein LigD \\
\hline PROM_v1_240013 & 2412 & $\operatorname{lig} A$ & DNA ligase \\
\hline PROM_v1_10007 & 237 & - & Ribosomal protein S18 RpsR \\
\hline PROM_v1_170101 & 375 & - & Ribosomal protein S12 (BS12) RpsI \\
\hline PROM_v1_170093 & 837 & - & Ribosomal protein L2 (BL2) RplB \\
\hline PROM_v1_90068 & 1578 & lig & Putative DNA ligase \\
\hline PROM_v1_120124 & 1182 & $\operatorname{lig} C$ & DNA ligase $\mathrm{C}$ \\
\hline PROM_v1_40293 & 1518 & $o b g E$ & ppGpp-binding GTPase involved in cell portioning; DNA repair and ribosome assembly \\
\hline PROM_v1_90030 & 465 & atl1 & $\begin{array}{l}\text { Alkylated DNA nucleotide flippase Atl1; Ada-like DNA-binding domain: nucleotide exci- } \\
\text { sion repair }\end{array}$ \\
\hline PROM_v1_140011 & 1119 & - & DNA alkylation repair protein \\
\hline PROM_v1_190139 & 1443 & $\operatorname{rad} A$ & DNA repair protein \\
\hline$\underline{\text { PROM v1 } 20165}$ & 2106 & $\operatorname{din} G$ & putative ATP-dependent helicase DinG homolog \\
\hline PROM_v1_220099 & 447 & $r n h A$ & $\begin{array}{l}\text { DNA replication, recombination, and repair; Degradation of proteins, peptides, and glyco- } \\
\text { peptides }\end{array}$ \\
\hline PROM_v1_10046 & 456 & - & Nucleotide-binding universal stress protein: UspA family \\
\hline PROM_v1_140049 & 510 & - & Universal stress protein UspA \\
\hline PROM_v1_190003 & 2562 & $\operatorname{clp} C$ & Class III stress response-related ATPase, AAA + superfamily \\
\hline PROM_v1_200143 & 489 & $\operatorname{sox} R n$ & DNA-binding transcriptional dual regulator, Fe-S center for redox-sensing \\
\hline PROM_v1_28004 & 837 & - & Ser/Thr protein kinase RdoA involved in Cpx stress response \\
\hline PROM_v1_350012 & 396 & - & Universal stress protein MSMEG_4207 \\
\hline PROM_v1_380020 & 420 & - & Stress response protein \\
\hline PROM_v1_480007 & 660 & - & Putative stress-induced transcription regulator \\
\hline PROM_v1_20114 & 204 & $\operatorname{csp} D$ & Cold-shock protein, molecular chaperone, RNA-helicase co-factor \\
\hline$\underline{\text { PROM v1 } 50089}$ & 2478 & gyrA & DNA gyrase subunit A \\
\hline PROM_v1_250073 & 2211 & gyrB & DNA gyrase subunit B \\
\hline PROM_v1_10073 & 282 & hup & DNA-binding protein $\mathrm{HB} 1$ \\
\hline PROM_v1_120020 & 2637 & polA & DNA polymerase I \\
\hline PROM_v1_50212 & 3378 & recB & RecBCD enzyme subunit RecB \\
\hline PROM_v1_50213 & 3402 & recC & RecBCD enzyme subunit RecC \\
\hline PROM_v1_50211 & 1866 & rec $D$ & RecBCD enzyme subunit RecD \\
\hline$\underline{\text { PROM_v1 } 30191}$ & 2067 & $u v r D$ & ATP-dependent DNA helicase UvrD2 \\
\hline PROM_v1_20292 & 810 & feu $V$ & Iron(III)-siderophore transporter: ATP binding component \\
\hline PROM_v1_50182 & 882 & $x p d C$ & Phage PBSX; manganese-containing peroxidase \\
\hline PROM_v1_150073 & 873 & $m n t A$ & Manganese transport system ATP-binding protein MntA \\
\hline PROM_v1_150072 & 864 & $m n t B$ & Manganese transport system ATP-binding protein MntB \\
\hline
\end{tabular}


Table 3 (continued)

\begin{tabular}{llll}
\hline Label & Length $(\mathrm{pb})$ & Gene & Functional \\
\hline PROM_v1_290076 & 894 & mntC & Manganese transport system ATP-binding protein MntC \\
PROM_v1_20214 & 1230 & - & Mn $^{2+}$ and Fe \\
PR transporters of the NRAMP family \\
PROM_v1_230090 & 1308 & mntH & Divalent metal cation transporter MntH \\
PROM_v1_250040 & 630 & sodA & Superoxide dismutase [Mn] \\
PROM_v1_70011 & 753 & - & Fe(3+)-transporting ATPase \\
PROM_v1_180005 & 1566 & fbpB & Fe(3+)-transport system permease protein SfuB \\
PROM_v1_150099 & 789 & fepC & Ferric enterobactin transport ATP-binding protein FepC \\
PROM_v1_80082 & 1320 & - & Mn ${ }^{2+}$ and Fe ${ }^{2+}$ transporters of the NRAMP family \\
PROM_v1_20146 & 825 & fecE & Iron-dicitrate transporter subunit \\
PROM_v1_20290 & 1020 & fecD & Iron-dicitrate ABC transporter (permease) \\
PROM_v1_240047 & 1308 & gltA & Glutamate synthase (large subunit, NADP-dependent) \\
PROM_v1_80125 & 762 & nuoC & NADH-quinone oxidoreductase subunit C \\
PROM_v1_120112 & 1380 & hisS & Histidine-tRNA ligase \\
PROM_v1_20071 & 3552 & dnaE & DNA polymerase III subunit alpha \\
PROM_v1_20016 & 948 & argF & Ornithine carbamoyltransferase \\
& & argC & \\
PROM_v1_400015 & 696 & nucS & Endonuclease NucS \\
\hline
\end{tabular}

Thus, the DNA repair machinery of $D$. radiodurans seems similar to that of other bacteria, such as isolate $\mathrm{PT} 9^{\mathrm{T}}$, with specificities contributing to radiation resistance and protection of proteins against oxidative damages (Makarova et al. 2001; Daly 2012; Lim et al. 2019).

To conclude, oxidative stress resistance of $\mathrm{PT}^{\mathrm{T}}$ against damages caused by gamma radiation, desiccation and oxidative stress generated by $\mathrm{H}_{2} \mathrm{O}_{2}$ was explained by the presence of a combination of enzymatic anti-oxidants (ROS-scavenging enzymes, such as catalase, superoxide dismutase) and non-enzymatic (like carotenoids and manganese $\mathrm{Mn}^{2+}$ ) defense mechanisms (Shashidhar et al. 2010; Slade and Radman 2011). These proteins are mainly associated with DNA repair and response to oxidative stress. Further functional analyses of these new oxidative stress-induced proteins will enhance our understanding of the regulatory mechanism underlying extreme resistance to oxidative stress in isolate $\mathrm{PT} 9^{\mathrm{T}}$. However, sufficient proteome protection is crucial for survival after irradiation because protein activity is required for essential processes including transcription, translation and DNA repair (Bellenberg et al. 2019).

\section{Secondary metabolites prediction}

The genome analysis of isolate $\mathrm{PT} 9^{\mathrm{T}}$ harbors multiple secondary metabolites related to defense mechanisms and strategies developed to survive under extreme conditions (Table 4).

As shown in Table 4, five biosynthesis gene clusters for secondary metabolites were identified in the genome of isolate $\mathrm{PT} 9^{\mathrm{T}}$-oligosaccharides, $\mathrm{t} 3 \mathrm{pks}$, lassopeptides, siderophores and ectoine.

Various microbial metabolites, such as oligosaccharides, carotenoids and compatible solutes (ectoine) were demonstrated to protect cells against IR (Beblo-Vranesevic et al. 2017). Cupriabactin is a carboxylate-type siderophore extracted from Cupriavidus necator JMP134, which demonstrated important roles in iron scavenging, bacterial motility, biofilm formation and oxidative stress resistance. Physiological analyses revealed that this system induced an increase
Table 4 AntiSMASH secondary metabolites of P. panici PT9 $^{\mathrm{T}}$

\begin{tabular}{llll}
\hline Cluster & Cluster type & Most similar known cluster & Length (bp) \\
\hline 1 & Oligosaccharide & Oligosaccharide & 51,475 \\
2 & t3pks & Arylomycin biosynthesis & 41,116 \\
& & Alkylresorcinol, Clarexpoxcin, Polyketide & \\
3 & Lassopeptide & SapB biosynthesis & 22,426 \\
5 & Siderophore & Desferrioxamine B biosynthesis & 12,643 \\
& Ectoine & Ectoine biosynthesis & 8697 \\
\hline
\end{tabular}


of the resistance of $C$. necator JMP134 to stress caused by aromatic compounds ( $\mathrm{Li}$ et al. 2019). In general, oxidative stress responses of bacteria have been observed to be part of complex phenomena such as biofilm formation, antibiotic resistance and pathogenicity (Cárdenas et al. 2012). Also, a secondary defense barrier consists of the induced expression of specific ROS degrading enzymes and repair systems for damaged macromolecules (Cabiscol et al. 2000).

Altogether, our findings allow us to develop an integrated understanding of the molecular basis of recovery from desiccation and other protein and DNA-damaging agents in PT9 ${ }^{\mathrm{T}}$ and roots-associated bacteria, particularly in the extreme environment of the Tunisian desert.

\section{Description of Promicromonospora panici sp. nov.}

Promicromonospora panici [pa'ni.ci. N.L. gen. n. panici referring to the isolation source, the xerophytic plant Panicum].

Aerobic, Gram-staining positive, non-spore-forming and non-motile actinobacterium. Forms well-developed branching septate hyphae that breaks up into fragments of various sizes and rod-shaped elements on the media tested after incubation at $30{ }^{\circ} \mathrm{C}$ for $72 \mathrm{~h}$. Colonies are white to yellowish-white with characteristic wrinkly surfaces. Cells grow well on soya flour mannitol, nutrient agar and tryptic soy agar media, but no growth was observed on LB agar medium. Optimal growth occurs at $28-37^{\circ} \mathrm{C}$ (optimum at $30{ }^{\circ} \mathrm{C}$ ) and $\mathrm{pH}$ 6.0-9.0. No growth in the presence of $2 \%$ $\mathrm{NaCl}$. Positive for catalase and oxidase.

The major fatty acids are anteiso-C15:0 and iso-C15:0. The polar lipid pattern is diphosphatidylglycerol (DPG), phosphatidylglycerol (PG), phosphatidylinositol (PI), phosphoglycolipid (PGL), unidentified glycolipids $\left(\mathrm{GL}_{1-3}\right)$, lipid (L) and phospholipid (PL).Whole-organism hydrolysates contain DL-2,6-diaminopimelic acid (DL-DAP), galactose, glucose and ribose as whole cell sugars.

The genome of the type strain is $6.5 \mathrm{Mb}$ with a GC content of $71.2 \mathrm{~mol} \%$. The GenBank/ENA accession number for the draft genome sequence of isolate $\mathrm{PT}^{\mathrm{T}}$ is PRJEB29453.

The type strain PT9 ${ }^{\mathrm{T}}\left(\mathrm{LMG} 31103^{\mathrm{T}}=\right.$ DSM $\left.108613^{\mathrm{T}}\right)$ was isolated from irradiated roots of $P$. turgidum collected from the Ksar Ghilane oasis, southern Tunisia.

Acknowledgement This work was performed under the auspices of Université Lyon 1, CNRS UMR 5557, Écologie Microbienne (France) and the National Center for Nuclear Sciences and Technology CNSTN (Tunisia) and in the ambit of the BIODESERT research program of the LR11-ES31 (BVBGR, ISBST, University of Manouba). The LABGeM (CEA/Genoscope \& CNRS UMR8030), the France Génomique and French Bioinformatics Institute national infrastructures (funded as part of Investissement d'Avenir program managed by Agence Nationale pour la Recherche, contracts ANR-10-INBS-09 and ANR11-INBS-0013) are acknowledged for support within the MicroScope annotation platform. We thank Betty Bigai, Corinne Sannaire and platform Genomique Environmental PGE, UMR CNRS 5557 for technical support.

\section{Compliance with ethical standards}

Conflict of interest The authors declare no conflict of interest.

\section{References}

Basu B, Apte SK (2012) Gamma radiation-induced proteome of Deinococcus radiodurans primarily targets DNA repair and oxidative stress alleviation. Mol Cell Proteom 11(M111):011734

Beblo-Vranesevic K, Galinski EA, Rachel R, Huber H, Rettberg P (2017) Influence of osmotic stress on desiccation and irradiation tolerance of (hyper)-thermophilic microorganisms. Arch Microbiol 199:17-28

Beblo-Vranesevic K, Bohmeier M, Perras AK et al (2018) Lack of correlation of desiccation and radiation tolerance in microorganisms from diverse extreme environments tested under anoxic conditions. FEMS Microbiol Lett 365(6):fny044

Bellenberg S, Huynh D, Poetsch A, Sand W, Vera M (2019) Proteomics reveal enhanced oxidative stress responses and metabolic adaptation in Acidithiobacillus ferrooxidans biofilm cells on pyrite. Front Microbiol 10:592

Benhamda C, Benkahla A, Ben Miled S, Ouled- Haddar H, del Carmen MC, Gtari M, Cherif A, Hofner B, Gjedira K, Sghaier H (2015) The RadioP1-an integrative web resource for radioresistant prokaryotes. Intech Open, London, pp 89-105

Bentchikou E, Servant P, Coste G, Sommer S (2010) A major role of the RecFOR pathway in DNA double-strand-break repair through ESDSA in Deinococcus radiodurans. PLoS Genet 6:e1000774

Blin K, Medema MH, Kazempour D, Fischbach MA, Breitling TRE, Weber T (2013) AntiSMASH 2.0-a versatile platform for genome mining of secondary metabolite producers. Nucleic Acids Res 41:W204-W212

Busse HJ, Zlamala C, Buczolits S, Lubitz W, Kämpfer P, Takeuchi M (2003) Promicromonospora vindobonensis sp. nov. and Promicromonospora aerolata sp. nov., isolated from the air in the medieval 'Virgilkapelle' in Vienna. Int J Syst Evol Microbiol 53:1503-1507

Cabiscol E, Tamarit J, Ros J (2000) Oxidative stress in bacteria and protein damage by reactive oxygen species. Internal Microbiol $3: 3-8$

Cárdenas JP, Moya F, Covarrubias P, Shmaryahu A, Levicán G, Holmes DS et al (2012) Comparative genomics of the oxidative stress response in bioleaching microorganisms. Hydrometallurgy $12: 162-167$

Castro-Wallace SL, Chiu CY, John KK, Stahl SE, Rubins KH et al (2017) Nanopore DNA sequencing and genome assembly on the international space station. Sci Rep 7:18022

Chen Y, Xue D, Sun W, Han J, Li J, Gao R, Zhou Z, Zhang W, Chen M, Lin M et al (2019) SRNA OsiA stabilizes catalase mRNA during oxidative stress response of Deincoccus radiodurans R1. Microorganisms 7:e422

Chun J, Oren A, Ventosa A, Christensen H, Arahal DR, da Costa MS Rooney AP, Yi H, Xu XW, De Meyer S, Trujillo ME (2018) Proposed minimal standards for the use of genome data for the taxonomy of prokaryotes. Int J Syst Evol Microbiol 68:461-466

Daly MJ (2012) Death by protein damage in irradiated cells. DNA Repair (Amst) 11:12-21

Flandrois JP, Perriere G, Gouy M (2015) leBIBIQBPP: a set of databases and a web tool for automatic phylogenetic analysis of prokaryotic sequences. BMC Bioinform 16:251 
Gabani P, Singh OV (2013) Radiation-resistant extremophiles and their potential in biotechnology and therapeutics. Appl Microbiol Biotechnol 97:993-1004

Gao L, Zhou Z, Chen X, Zhang W, Lin M, Chen M (2020) Comparative proteomics analysis reveals new features of the oxidative stress response in the polyextremophilic bacterium Deinococcus radiodurans. MDPI J Microorgan 8:451

Gholami M, Etemadifar Z, Bouzari M (2015) Isolation a new strain of Kocuria rosea capable of tolerating extreme conditions. J Environ Radioact 144:113-119

Goris J, Konstantinidis KT, Klappenbach JA, Coenye T, Vandamme P, Tiedje JM (2007) DNA-DNA hybridization values and their relationship to whole-genome sequence similarities. Int J Syst Evol Microbiol 57(1):81-91

Guindon S, Dufayard JF, Lefort V, Anisimova M, Hordijk W, Gascuel O (2010) New algorithms and methods to estimate maximumlikelihood phylogenies: assessing the performance of PhyML 3.0. System Biol 59(3):307-321

Guo L, Liu C, Zhao J, Li C, Guo S, Fan J, Li J, Wang X, Xiang W (2016) Promicromonospora alba sp. nov., an actinomycete isolated from the cuticle of Camponotus japonicas Mayr. Int J Syst Evol Microbiol 66:1340-1345

Hamedi J, Dehhaghi M, Mohammdipanah F (2015) Isolation of extremely heavy metal resistant strains of rare actinomycetes from high metal content soils in Iran. Int J Environ Res 9(2):475-480

Izumikawa M, Takagi M, Shin-Ya K (2011) Isolation of a novel macrocyclic dilactone-JBIR-101-from Promicromonospora sp. RL26. J Antibiot 64:689-691

Jin L, Zhao J, Jiang S, Zhao Y, Han X, Guo X, Wang X, Xiang W (2018) Promicromonospora viridis sp. nov., a novel actinomycete isolated from soil. Antonie van Leeuwenhoek.

Kaewkla O, Franco CMM (2017) Promicromonospora callitridis sp. nov., an endophytic actinobacterium isolated from the surfacesterilized root of an Australian native pine tree. Int J Syst Evol Microbiol 67:3559-3563

Kaewkla O, Franco CMM (2019) Actinomycetospora callitridis sp. nov., an endophytic actinobacterium isolated from the surfacesterilised root of an Australian native pine tree. Antonie Van Leeuwenhoek 112:331-337

Kang SM, Khan AL, Hamayun M, Hussain J, Joo GJ, You YH, Kim JG, Lee IJ (2012) Gibberellin-producing Promicromonospora sp. SE188 improves Solanum lycopersicum plant growth and influences endogenous plant hormones. J Microbiol 50:902-909

Kang SM, Khan AL, Waqas M, You YH, Kim JH, Kim JG, Hamayun M, Lee IJ (2014) Plant growth promoting rhizobacteria reduce adverse effects of salinity and osmotic stress by regulating phytohormones and antioxidants in Cucumis sativus. J Plant Interact 9:673-682

Krasilnikov NA, Kalakoutskii LV, Kirillova NF (1961) A new genus of Actinomycetales, Promicromonospora gen. nov. vol 1. Bull Acad Sci USSR (Ser Biol).

Kroppenstedt RM, Goodfellow M (2006) The family Thermomonosporaceae: Actinocorallia, Actinomadura, Spirillispora and Thermomonospora. Archaea, Bacteria, Firmicutes, Actinomycetes. In: Dworkin M, Falkow S, Rosenberg E, Schleifer KH, Stackebrandt $\mathrm{E}$ (eds) The prokaryotes: a handbookon the biology of bacteria. Springer, New York, pp 682-724

Kumar M, Joshi A, Kashyap R, Khanna S (2011) Production of xylanase by Promicromonospora sp. MARS with rice straw under non sterile conditions. Process Biochem 46:1614-1618

Lechevalier MP, Lechevalier HA (1970) Chemical composition as a criterion in the classification of aerobic actinomycetes. Int J Syst Bacteriol 20:435-443

Li WJ, Xu P, Schumann P, Zhang YQ, Pukall R, Xu LH, Stackebrandt E, Jiang CL (2007) Georgenia ruanii sp. nov., a novel actinobacterium isolated from forest soil in Yunnan (China), and emended description of the genus Georgenia. Int J Syst Evol Microbiol 57:1424-1428

Li C, Zhu L, Pan D, Li S, Xiao H, Zhang Z, Shen X, Wang Y, Long M (2019) Siderophore mediated iron acquisition enhances resistance to oxidative and aromatic compound stress in Cupriavidus necator JMP134. Appl Environ Microbiol 85:e01938-e2018

Lim S, Jung JH, Blanchard L, de Groot A (2019) Conservation and diversity of radiation and oxidative stress resistance mechanisms in Deinococcus species. FEMS Microbiol Rev 43(1):19-52

Makarova KS, Aravind L, Wolf YI, Tatusov RL, Minton KW, Koonin EV, Daly MJ (2001) Genome of the extremely radiationresistant bacterium Deinococcus radiodurans viewed from the perspective of comparative genomics. Microbiol Mol Biol R 65:44-79

Marmur J (1961) A procedure for the isolation of deoxyribonucleic acid from microorganisms. J Mol Biol 3:208

MattimoreBattista VJR (1996) Radioresistance of Deinococcus radiodurans: functions necessary to survive ionizing radiation are also necessary to survive prolonged desiccation. J Bacteriol 178:633-637

Medema MH, Blin K, Cimermancic P, de Jager V, Zakrzewski P, Fischbach MA, Weber T, Takano E, Breitling R (2011) antiSMASH: rapid identification, annotation and analysis of secondary metabolite biosynthesis gene clusters in bacterial and fungal genome sequences. Nucleic Acids Res 39:W339-W346

Meier-Kolthoff J, Göker M (2019) TYGS is an automated highthroughput platform for state-of-the-art genome-based taxonomy. Nat Commun 10:2182

Meier-Kolthoff JP, Auch AF, Klenk H-P, Göker M (2013) Genome sequence-based species delimitation with confidence intervals and improved distance functions. BMC Bioinform 14:60

Minh BQ, Nguyen AT, von Haeseler A (2013) Ultrafast approximation for phylogenetic bootstrap. Mol Biol Evol 30(5):1188-1195

Minnikin D, O'Donnell A, Goodfellow M, Alderson G, Athalye M, Schaal A, Parlett JH (1984) An integrated procedure for the extraction of bacterial isoprenoid quinones and polar lipids. J Microbiol Methods 2:233-241

Mohammadipanah F, Montero-Calasanz MD, Schumann P, Sproer C, Rohde M, Klenk HP (2017) Promicromonospora kermanensis sp. nov., an actinobacterium isolated from soil. Int J Syst Evol Microbiol 67:262-267

Morini J, Babini G, Barbieri S, Baiocco G, Ottolenghi A (2017) The interplay between radioresistant Caco- 2 cells and the immune system increases epithelial layer permeability and alters signalling protein spectrum. Front Immunol 8:233

Mosmann T (1983) Rapid colorimetric assay for cellular growth and survival: application to proliferation and cytotoxicity assays. J Immunol Methods 65:55-63

Munteanu A, Uivarosi V, Andries A (2015) Recent progress in understanding the molecular mechanisms of radioresistance in Deinococcus bacteria. Extremophiles 19:707-719

Qin S, Jiang JH, Klenk HP, Zhu WY, Zhao GZ, Zhao LX, Tang SK, Xu LH, Li WJ (2012) Promicromonospora xylanilytica sp. nov., an endophytic actinomycete isolated from surface-sterilized leaves of the medicinal plant Maytenus austroyunnanensis. Int J Syst Evol Microbiol 62:84-89

Richter M, Rossello-Mora R (2009) Shifting the genomic gold standard for the prokaryotic species definition. Proc Natl Acad Sci USA 106:19126-19131

Schleifer KH, Kandler O (1972) Peptidoglycan types of bacterial cell walls and their taxonomic implications. Bacteriol Rev 36:407-477

Schumann P, Stackebrandt E (2012) The family Promicromonosporaceae. Bergey's manual of systematic bacteriology. Springer, New York

Schumann P, Weiss N, Stackebrandt E (2001) Reclassification of Cellulomonas cellulans (Stackebrandt and Keddie 1986) as 
Cellulosimicrobium cellulans gen. nov., comb. nov. Int J Syst Evol Microbiol 51:1007-1010

Sghaier H, Narumi I, Satoh K, Ohba H, Mitomo H (2007) Problems with the current deinococcal hypothesis: an alternative theory. Theory Biosciences 126:43-45

Sghaier H, Ghedira K, Benkahla A, Barkallah I (2008) Basal DNA repair machinery is subject to positive selection in ionizing-radiation-resistant bacteria. BMC Genom 9:297

Shashidhar R, Kumar SA, Misra HS, Bandekar JR (2010) Evaluation of the role of enzymatic and non-enzymatic antioxidant systems in the radiation resistance of Deinococcus. Can J Microbiol 56:195-201

Slade D, Radman M (2011) Oxidative stress resistance in Deinococcus radiodurans. Microbiol Mol Biol R 75:133-191

Slade D, Lindner AB, Paul G, Radman M (2009) Recombination and replication in DNA repair of heavily irradiated Deinococcus radiodurans. Cell 136:1044-1055

Smibert R, Krieg N (1994) Phenotypic characterization. In: Gerhardt $\mathrm{P}$ (ed) Methods for general and molecular bacteriology. American Society for Microbiology, Washington, pp 607-654

Stackebrandt E, Ebers J (2006) Taxonomic parameters revisited: tarnished gold standards. Microbiol Today 33:152-155

Staneck JL, Roberts GD (1974) Simplified approach to identification of aerobic actinomycetes by thin layer chromatography. J Appl Microbiol 28:226-231

Sun LN, Zhang YF, He L, Chen ZJ, Wang QY, Qian M, Sheng XF (2010) Genetic diversity and characterization of heavy metalresistant-endophytic bacteria from two copper-tolerant plant species on copper mine wasteland. Bioresour Technol 101:501-509

Tanaka M, Earl AM, Howell HA, Park MJ, Eisen JA, Peterson SN, Battista JR (2004) Analysis of Deinococcus radiodurans's transcriptional response to ionizing radiation and desiccation reveals novel proteins that contribute to extreme radioresistance. Genet Soc Am 168:21-33

Thomas L, Ram H, Kumar A, Singh VP (2016) Production, optimization, and characterization of organic solvent tolerant cellulases from a lignocellulosic waste-degrading actinobacterium, Promicromonospora sp. VP111. Appl Biochem Biotechnol 179:863-879

Timmins J, Moe E (2016) A decade of biochemical and structural studies of the DNA repair machinery of Deinococcus radiodurans: major findings, functional and mechanistic insight and challenges. Comput Struct Biotechnol J 14:168-176
Trifinopoulos J, Nguyen LT, von Haeseler A, Minh BQ (2016) W-IQTREE: a fast online phylogenetic tool for maximum likelihood analysis. Nucleic Acids Res 44:232-235

Ujaoney AK, Padwal MK, Basu B (2017) Proteome dynamics during post-desiccation recovery reveal convergence of desiccation and gamma radiation stress response pathways in Deinococcus radiodurans. Biochim Biophys Acta Proteins Proteom 1865:1215-1226

Vallenet D, Calteau A, Cruveiller S, Gachet M, Lajus A, Josso A, Mercier J, Renaux A, Rollin J, Rouy Z, Roche D, Scarpelli C, Médigue C (2017) MicroScope in 2017: an expanding and evolving integrated resource for community expertise of microbial genomes. Nucleic Acids Res 45:517-528

Ventorino V, Aliberti A, Faraco V, Robertiello A, Giacobbe S, Ercolini D, Amore A, Fagnano M, Pepe O (2015) Exploring the microbiota dynamics related to vegetable biomasses degradation and study of lignocellulose-degrading bacteria for industrial biotechnological application. Sci Rep 5:8161

Wayne LG, Brenner DJ, Colwell RR, Grimont PAD, Kandler O, Krichevsky MI, Moore LH, Moore WEC, Murray RGE, Stackebrandt E, Starr MP, Truper HG (1987) Report of the Ad Hoc Committee On Reconciliation Of Approaches To Bacterial Systematics. Int J Syst Evol Microbiol 37:463-464

Weber T, Blin K, Duddela S et al (2015) antiSMASH 3.0-a comprehensive resource for the genome mining of biosynthetic gene clusters. Nucleic Acids Res 43:237-243

Yoon SH, Ha SM, Kwon S, Lim J, Kim Y, Seo H, Chun J (2017) Introducing EzBioCloud: a taxonomically united database of $16 \mathrm{~S}$ rRNA gene sequences and whole-genome assemblies. Int J Syst Evol Microbiol 67:1613-1617

Zheng W, Li D, Zhao J, Liu C, Zhao Y, Xiang W, Wang X (2017) Promicromonospora soli sp. nov., a novel actinomycete isolated from soil. Int J Syst Evol Microbiol 67:3829-3833

Zothanpuia PAK, Leo VV, Chandra P, Kumar B, Nayak C, Hashem A, Abd-Allah EF, Alqarawi AA, Singh BP (2018) Bioprospection of actinobacteria derived from freshwater sediments for their potential to produce antimicrobial compounds. Microb Cell Fact 17:68

Publisher's Note Springer Nature remains neutral with regard to jurisdictional claims in published maps and institutional affiliations.

\section{Affiliations}

\section{Sihem Guesmi $i^{1,2} \cdot$ Imen Nouioui $^{3,4} \cdot$ Petar Pujic $^{5,6} \cdot$ Audrey Dubost $^{5,6} \cdot$ Afef Najjari $^{7} \cdot$ Kais Ghedira $^{8} \cdot$ José M. Igual $^{9}$. Ameur Cherif $^{10}$. Hans-peter Klenk ${ }^{3} \cdot$ Haïtham Sghaier ${ }^{2,10}$. Philippe Normand $d^{5,6}$}

1 National Agronomy Institute of Tunisia, Avenue Charles Nicolle, 1082 Tunis, Mahrajène, Tunisia

2 Laboratory "Energy and Matter for Development of Nuclear Sciences" (LR16CNSTN02), National Center for Nuclear Sciences and Technology, Sidi Thabet Technopark, 2020 Sidi Thabet, Tunisia

3 School of Natural and Environmental Sciences, Newcastle University, Ridley Building 2, Newcastle upon Tyne NE1 7RU, UK

4 Leibniz Institute DSMZ-German Collection of Microorganisms and Cell Cultures, Braunschweig, Germany

5 Université de Lyon, Université Lyon 1, Lyon, France
6 CNRS, UMR 5557, Écologie Microbienne, UMR1418, INRA, 69622 Villeurbanne Cedex, France

7 Université de Tunis el Manar, Faculté des Sciences de Tunis, LR03ES03 Microorganismes et Biomolécules Actives, 2092 Tunis, Tunisia

8 Laboratory of Bioinformatics, Biomathematics and Biostatistics-LR16IPT09, Institut Pasteur de Tunis, Université de Tunis El Manar, 1002 Tunis, Tunisia

9 Instituto de Recursos Naturales y Agrobiología de Salamanca, Consejo Superior de Investigaciones Científicas (IRNASA-CSIC), c/Cordel de Merinas 40-52, 37008 Salamanca, Spain 
10 University Manouba, ISBST, BVBGR-LR11ES31,

Biotechpole Sidi Thabet, 2020 Ariana, Tunisia 